\title{
Primary angiitis of the central nervous system: a study of histopathological patterns and review of the literature
}

\author{
Vaishali Suri ${ }^{1}$, Aanchal Kakkar ${ }^{1}$, Mehar C. Sharma ${ }^{1}$, Madakasira V. Padma ${ }^{2}$, Ajay Garg ${ }^{3}$, Chitra Sarkar ${ }^{1}$ \\ ${ }^{1}$ Department of Pathology, ${ }^{2}$ Department of Neurology, and ${ }^{3}$ Department of Neuroradiology, All India Institute of Medical Sciences \\ (AlIMS), New Delhi, India
}

\begin{abstract}
Primary angiitis of the central nervous system (PACNS) is a rare form of vasculitis of unknown aetiology. Multifaceted clinical manifestations, non-specific MRI findings, a broad range of differential diagnoses and diverse pathological appearances prove to be a diagnostic challenge. However, a prompt diagnosis and aggressive treatment are crucial to avoid permanent damage. Hence, we present the clinico-pathological spectrum of this entity and highlight the limitations of currently available diagnostic modalities. We describe in detail the histopathological findings of eight cases of PACNS diagnosed at the Department of Pathology, AIIMS, over a period of eight years. Eight cases of PACNS were identified during this period. Five cases (62.5\%) showed features of granulomatous vasculitis, two (25\%) showed lymphocytic vasculitis and one case (12.5\%) showed a predominantly necrotizing pattern of vasculitis. Diagnosis of PACNS is a challenge and requires a high index of clinical suspicion. Appropriate work-up to exclude other conditions is mandatory. Brain biopsy is useful in making the diagnosis and ruling out mimicking conditions.
\end{abstract}

Key words: central nervous system, primary angiitis, vasculitis, granulomatous inflammation.

\section{Introduction}

Primary angiitis of central nervous system (PACNS) is a rare and diagnostically challenging form of vasculitis, which primarily affects small and medium-sized vessels supplying the brain parenchyma, spinal cord and leptomeninges [1]. Synonyms for this entity include "isolated angiitis of CNS" and "primary CNS vasculitis" (PCNSV). An annual incidence of 2.4 cases per million population has been reported in North America [33]. Majority of patients present in the fourth to sixth decade, with male preponderance [24]. There are no useful animal models to aid our understanding of this disease. It was first described as 'an unknown form of angiitis' by Harbitz in 1922 [15] and was considered a distinct clinical entity in 1959 by Cravioto and Feigin who coined the term "noninfectious granulomatous angiitis" with a predilection for the nervous system [10]. Primary angiitis of central nervous system remained rare with only 46 cases reported in the literature by 1986. In 1988, Calabrese and Mallek proposed the definite diagnostic criteria, which were later modified by Birnbaum et al. in 2009 [5,7].

The clinical presentations are diverse and non-specific [12]. Differential diagnoses include secondary vasculitides, collagen vascular disorders, certain viral and bacterial infections, and substance abuse $[29,40]$. Laboratory investigations indicative of systemic vas- 
culitis are usually normal. CSF shows modest lymphocytic pleocytosis and raised protein levels [7].

MRI is abnormal in almost all patients, and abnormalities may be seen in the subcortical white matter, deep gray matter, deep white matter, and the cerebral cortex $[9,13,17]$. Angiogram shows characteristic alternating stenosis and dilatation, but is less specific and has been observed to be as low as 30\% $[11,16,33]$. A definite diagnosis can be made only on the basis of biopsy findings [22]. Due to the segmental nature of the lesions, even biopsy may be negative in up to $35 \%$ of biopsies [8,12]. Based on distinct clinical, radiological and histopathological profiles, several clinical subsets of this entity have been described which vary in their treatment options and outcome [35]. We herein report eight cases of PACNS diagnosed by CNS biopsy over a period of eight years at the Department of Pathology, AlIMS, and discuss the advancements in clinical, radiological and histopathological patterns.

\section{Material and methods}

The records of all patients presenting in 2005-2012 with a clinical diagnosis of PACNS were retrieved. There were thirteen cases with a provisional diagnosis of PACNS. The routine hematoxylin and eosin stained histopathology slides were evaluated independently by three neuropathologists (CS, MCS, VS). In addition, special stains viz. Masson's trichrome, Verhoeff's Van Gieson (VVG), reticulin stain, Congo red, and immunohistochemical staining with antibodies for CD3, CD20, CD4, CD8, CD68, neurofilament protein (NF), myelin basic protein (MBP), glial fibrillary acidic protein (GFAP) and beta-amyloid were performed where required. The cases were classified on the basis of the classification proposed by Miller et al. in 2009 [22]. A final diagnosis of PACNS was rendered in eight cases.

\section{Clinical and radiological features}

All eight patients were males. The age range was 19 to 48 years, with mean age of 33.5 years. Majority of patients presented with a history of seizures ( $7 / 8$; $87.5 \%)$, headache $(5 / 8 ; 62.5 \%)$ and sudden onset weakness $(5 / 8 ; 62.5 \%)$. Remaining symptoms varied with the site of intraparenchymal haemorrhage, and included visual disturbances, difficulty in walking, slurring of speech, impaired memory, and altered behaviour (Table I). On radiology, 6 patients (75\%) had bilateral supratentorial patchy to confluent white matter lesions, with multiple micro- and macrohaemorrhages. Similar lesions were seen in the infratentorial compartment in one patient, involving the brainstem and cerebellar hemispheres (case 8). One patient (case 2) showed confluent white matter signal changes in the right and left temporal lobes, left frontoparietal lobe, bilateral cerebral peduncles and pons. However, microhaemorrhages were not seen. Seven patients underwent intra-arterial digital subtraction angiography (IADSA), which was normal in all but one patient (14\%). IADSA in this patient (case 3) showed irregularity and tortuosity of venous channels, suggesting vasculitis (Fig. 1). One patient (case 6) underwent MR angiography, which showed multiple focal stenoses in left A1 segment of anterior cerebral artery, as well as right pericallosal and callosomarginal arteries, suggesting vasculitis. Radiological features of case 6 are seen in Figure 2 .

\section{Microscopic findings}

On histopathological examination, five of the eight cases (62.5\%) showed features of granulomatous vasculitis, which was typified by transmural destruction of the vessel wall by epithelioid cell granulomas, accompanied by lymphocytes with or without giant cells (Fig. 3). This pattern was seen involving the leptomeningeal as well as parenchymal vessels in all but one case (Table I). One of the cases also showed the presence of necrotizing vasculitis involving parenchymal arterioles. Apart from this case, necrotizing vasculitis with transmural fibrinoid necrosis and acute inflammatory cell infiltrate was seen in one other case. The remaining two cases showed features of lymphocytic vasculitis (Fig. 4), with infiltration of the vessel wall by lymphocytes and occasional plasma cells, without significant spill over into the adjacent parenchyma. On immunohistochemistry, the inflammatory cells comprised predominantly of CD3 positive T lymphocytes.

The surrounding brain parenchyma showed evidence of haemorrhage, ischaemia, and reactive gliosis in most of the cases. Verhoeff's Van Gieson stain showed focal to complete disruption of the internal elastic lamina in all the cases. Congo red stain and immunohistochemistry for beta-amyloid did not demonstrate amyloid deposits in any of the cases. Of the cases showing abnormalities on angiography, both showed granulomatous vasculitis (cases 
Table I. Clinical and histological features in cases diagnosed as PACNSs

\begin{tabular}{|c|c|c|c|c|c|c|}
\hline $\begin{array}{l}\text { Case } \\
\text { no. }\end{array}$ & Age & Sex & Clinical features & Histological patterns & Site of involvement & Other features \\
\hline 1. & $\begin{array}{c}38 \\
\text { years }\end{array}$ & Male & $\begin{array}{l}\text { Recurrent headache, } \\
\text { seizures }-4 \text { yrs } \\
\text { Left homonymous } \\
\text { hemianopia - } 9 \text { mths }\end{array}$ & Granulomatous vasculitis & $\begin{array}{c}\text { Meningeal blood } \\
\text { vessels }\end{array}$ & $\begin{array}{l}\text { Subpial gliosis, } \\
\text { reactive gliosis } \\
\text { in cortex }\end{array}$ \\
\hline 2. & $\begin{array}{c}43 \\
\text { years }\end{array}$ & Male & $\begin{array}{c}\text { Recurrent seizures - } 4 \text { mths } \\
\text { Altered behaviour, } \\
\text { slurring of speech, right } \\
\text { hemiparesis - } 1 \text { episode }\end{array}$ & $\begin{array}{c}\text { Acute necrotizing } \\
\text { vasculitis }\end{array}$ & $\begin{array}{c}\text { Parenchymal blood } \\
\text { vessels }\end{array}$ & $\begin{array}{c}\text { Hemorrhagic } \\
\text { necrosis of white } \\
\text { matter }\end{array}$ \\
\hline 3. & $\begin{array}{c}28 \\
\text { years }\end{array}$ & Male & $\begin{array}{l}\text { Headache }-6 \text { mths } \\
\text { Seizures }-4 \text { mths } \\
\text { Sudden onset weakness in } \\
\text { the upper limb - } 1 \text { episode }\end{array}$ & Granulomatous vasculitis & $\begin{array}{l}\text { Meningeal } \\
\text { and parenchymal } \\
\text { blood vessels }\end{array}$ & $\begin{array}{l}\text { Ischemic changes } \\
\text { in neurons }\end{array}$ \\
\hline 4. & $\begin{array}{c}19 \\
\text { years }\end{array}$ & Male & $\begin{array}{c}\text { Seizures }-1 \text { year } \\
\text { Sudden onset weakness - } \\
2 \text { episodes }\end{array}$ & Lymphocytic vasculitis & $\begin{array}{c}\text { Parenchymal blood } \\
\text { vessels }\end{array}$ & - \\
\hline 5. & $\begin{array}{c}48 \\
\text { years }\end{array}$ & Male & $\begin{array}{l}\text { Intermittent headache - } \\
2 \text { years } \\
\text { Seizures }-3 \text { months }\end{array}$ & Granulomatous vasculitis & $\begin{array}{l}\text { Meningeal } \\
\text { and parenchymal } \\
\text { blood vessels }\end{array}$ & Subpial gliosis \\
\hline 6. & $\begin{array}{c}27 \\
\text { years }\end{array}$ & Male & $\begin{array}{c}\text { Recurrent seizures }-5 \text { yrs } \\
\text { Difficulty in speaking - } \\
2 \text { yrs }\end{array}$ & $\begin{array}{c}\text { Granulomatous vasculitis } \\
\text { with necrotizing } \\
\text { vasculitis }\end{array}$ & $\begin{array}{l}\text { Meningeal } \\
\text { and parenchymal } \\
\text { blood vessels }\end{array}$ & $\begin{array}{l}\text { Ischemic changes } \\
\text { in neurons }\end{array}$ \\
\hline 7. & $\begin{array}{c}26 \\
\text { years }\end{array}$ & Male & $\begin{array}{c}\text { Recurrent headache }-5 \text { yrs } \\
\text { Seizures }-4 \text { months } \\
\text { Difficulty in walking - } \\
4 \text { months } \\
\text { Sudden onset weakness - } \\
2 \text { episodes }\end{array}$ & Granulomatous vasculitis & $\begin{array}{c}\text { Meningeal } \\
\text { and parenchymal } \\
\text { blood vessels }\end{array}$ & $\begin{array}{l}\text { Fresh thrombi } \\
\text { in occasional blood } \\
\text { vessels }\end{array}$ \\
\hline 8. & $\begin{array}{c}39 \\
\text { years }\end{array}$ & Male & $\begin{array}{l}\text { Intermittent headache - } \\
2 \text { yrs } \\
\text { Sudden onset weakness - } \\
2 \text { episodes } \\
\text { Impaired memory, altered } \\
\text { behaviour - } 6 \text { months }\end{array}$ & Lymphocytic vasculitis & $\begin{array}{c}\text { Parenchymal blood } \\
\text { vessels }\end{array}$ & - \\
\hline
\end{tabular}

3 and 6), with the latter also showing foci of necrotizing vasculitis.

\section{Discussion}

The term "Vasculitides" encompasses a heterogeneous group of disorders characterized by inflammatory disease of arteries, veins, or both that results in histologically demonstrable structural injuries to the vessel wall, often accompanied by thrombosis and evidence of ischemic damage to the tissues served by the affected blood vessels [38]. Vasculitis of the central nervous system (CNS) may occur in any of the systemic vasculitides or may be secondary to connective tissue disorders, infections, neoplasms, or due to substance abuse [8].
'Isolated angiitis' affecting either the central nervous system or the spinal cord is a rare form of vasculitis, where there is neither any clinically overt systemic vasculitis, nor any underlying causal disease [38]. It usually involves leptomeningeal, cortical and subcortical medium-sized arteries and, less frequently, vein and venules [8].

The incidence of PACNS from Olmsted County, Minnesota (USA) has been estimated at 2.4 cases per 1,000,000 person-years [33]. Amongst patients attending the regional vasculitis clinic at Manchester Royal Infirmary between 1988 and $2003(n=105)$, the frequency of PACNS was 10.5\% [21]. The frequency of PACNS amongst vasculitides and connective tissue diseases associated with a diagnosis of CNS 


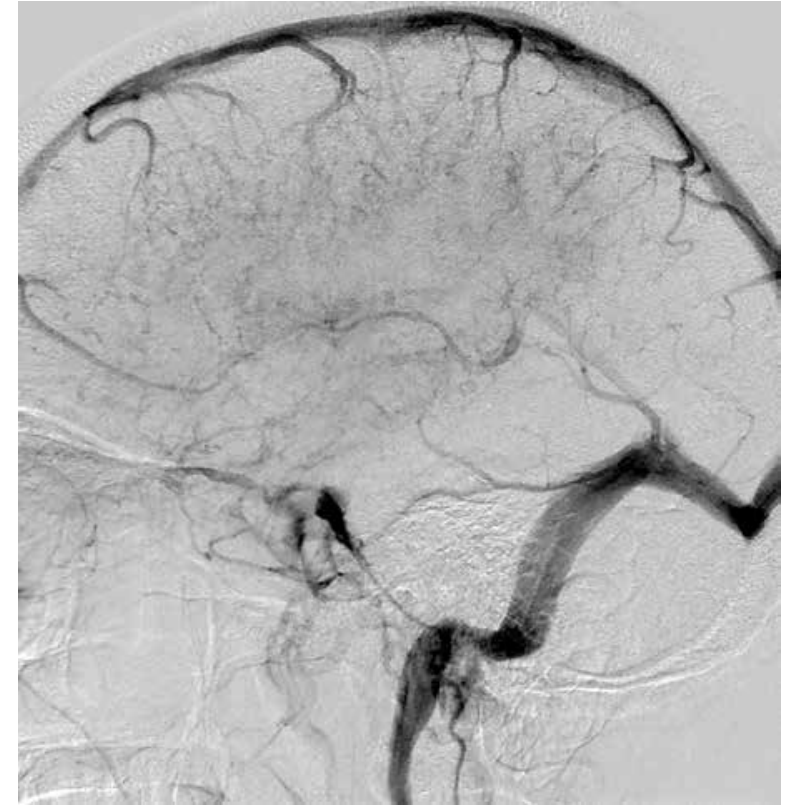

Fig. 1. Venous phase of left internal carotid artery digital subtraction angiogram shows irregularities and indistinct pattern of deep veins suggestive of vasculitis.

vasculitis or angiitis at the Mayo Clinic over a 17-year period was $64 \%$. Thus, it represents the most frequent vasculitis involving the CNS.

\section{Pathogenesis}

Data on the pathogenesis and immunological mechanisms involved in PACNS are sparse, as there are no useful animal models to aid our understand- ing of the disease. It is possible that viral infections initiate the inflammatory process that somehow becomes self-sustaining, or there may be a genetic predisposition in certain individuals, leading to an enhanced risk of a vasculitic process when there is an exposure to a particular antigen that "sets off" the immune system $[18,20,27]$.

\section{Diagnostic criteria}

Clinical, laboratory, neuroimaging and histopathological analysis are important both for making a correct diagnosis and for excluding a wide variety of other conditions which may have a similar presentation. Definite criteria for diagnosis were proposed by Calabrese and Mallek in 1988 [5] and they include: (1) history of an unexplained neurologic deficit that remains after a vigorous diagnostic workup, including lumbar puncture and neuroimaging studies; (2) either classic angiographic evidence of vasculitis or histopathologic evidence of vasculitis within the CNS; (3) no evidence of systemic vasculitis or any other condition to which the angiographic or pathologic evidence can be attributed. A diagnosis of PACNS is made if all the above criteria are satisfied. To prevent misdiagnosis of reversible vasoconstriction syndrome (RCVS) as PACNS, Birnbaum et al. in 2009 suggested the following modification: definite diagnosis is given if analysis of a tissue biopsy specimen confirms the presence of vasculitis. Probable diagnosis is rendered in the absence of tissue confirmation, if there are high probability findings on an

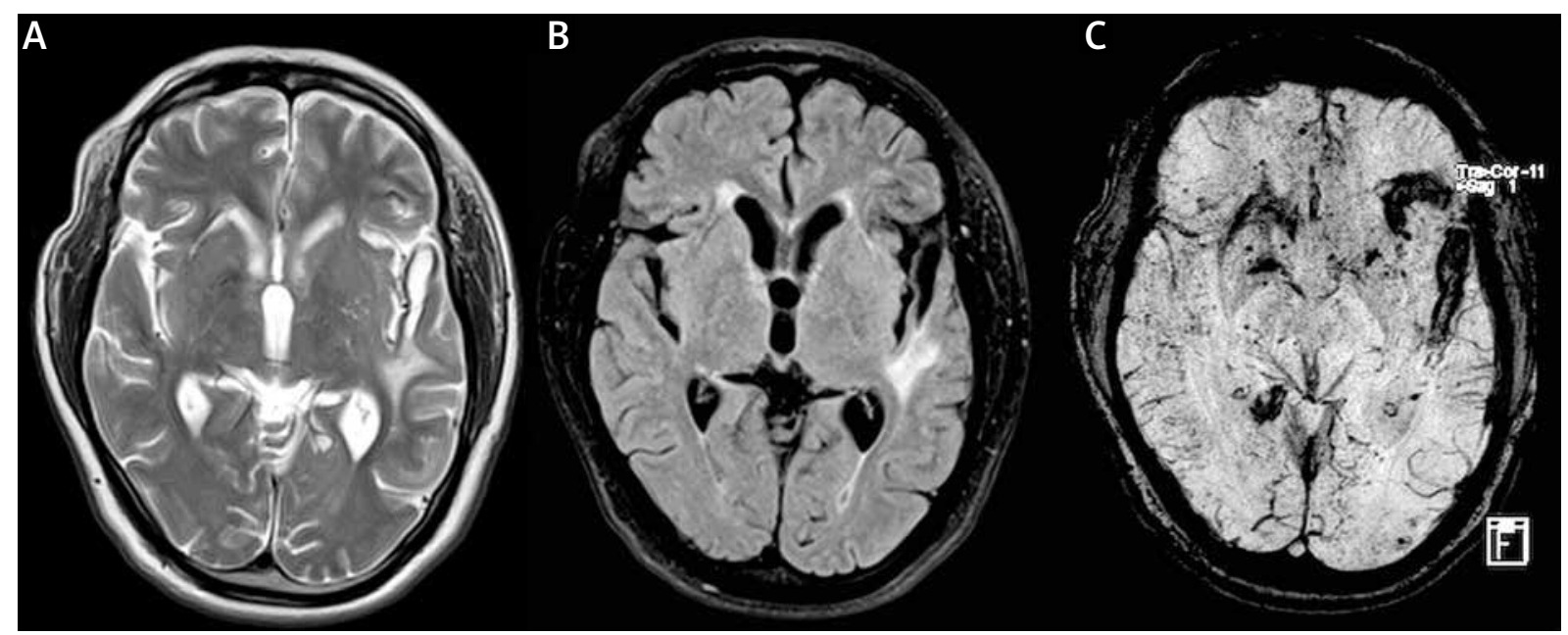

Fig. 2. T2 weighted MR (A), FLAIR (B) and susceptibility weighted images (C) showing bilateral supratentorial white matter lesions, along with micro- and macro-haemorrhages. 

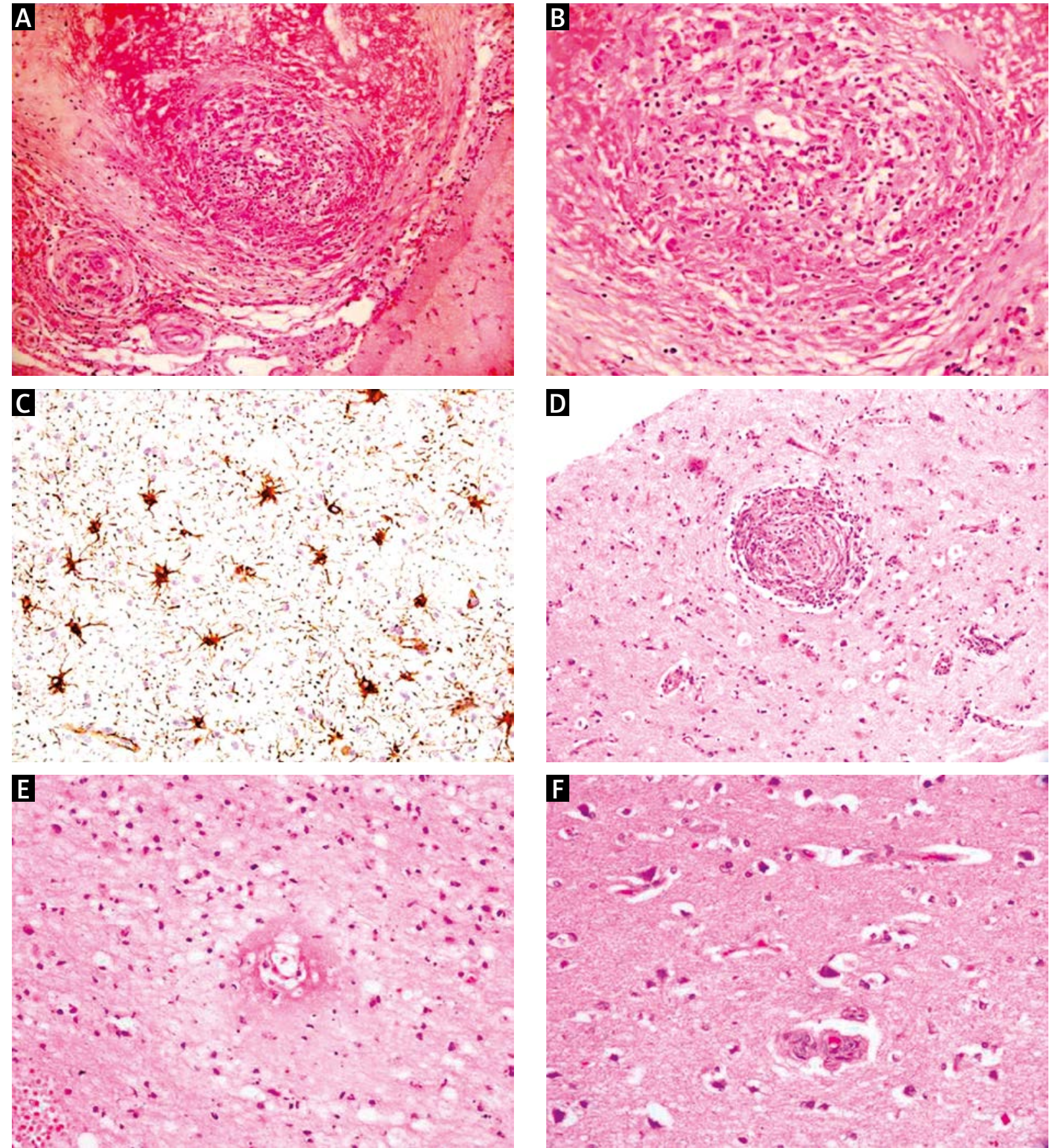

Fig. 3. Photomicrographs of case 1 showing (A) transmural granulomatous inflammation involving small and medium-sized leptomeningeal arteries ( $H \& E, \times 200)$. High magnification view (B) shows lymphocytes, epithelioid histiocytes and giant cells $(H \& E, \times 400)$. GFAP stain (C) highlights reactive astrocytosis (IHC, $\times 400$ ). Similar granulomatous vasculitis seen in a small cortical artery (D; H\&E, ×200) in case 6, along with transmural fibrinoid necrosis $(E)$ in an adjacent cortical arteriole $(H \& E, \times 400)$. Surrounding cortex (F) shows ischemic neurons $(H \& E, \times 400)$. 

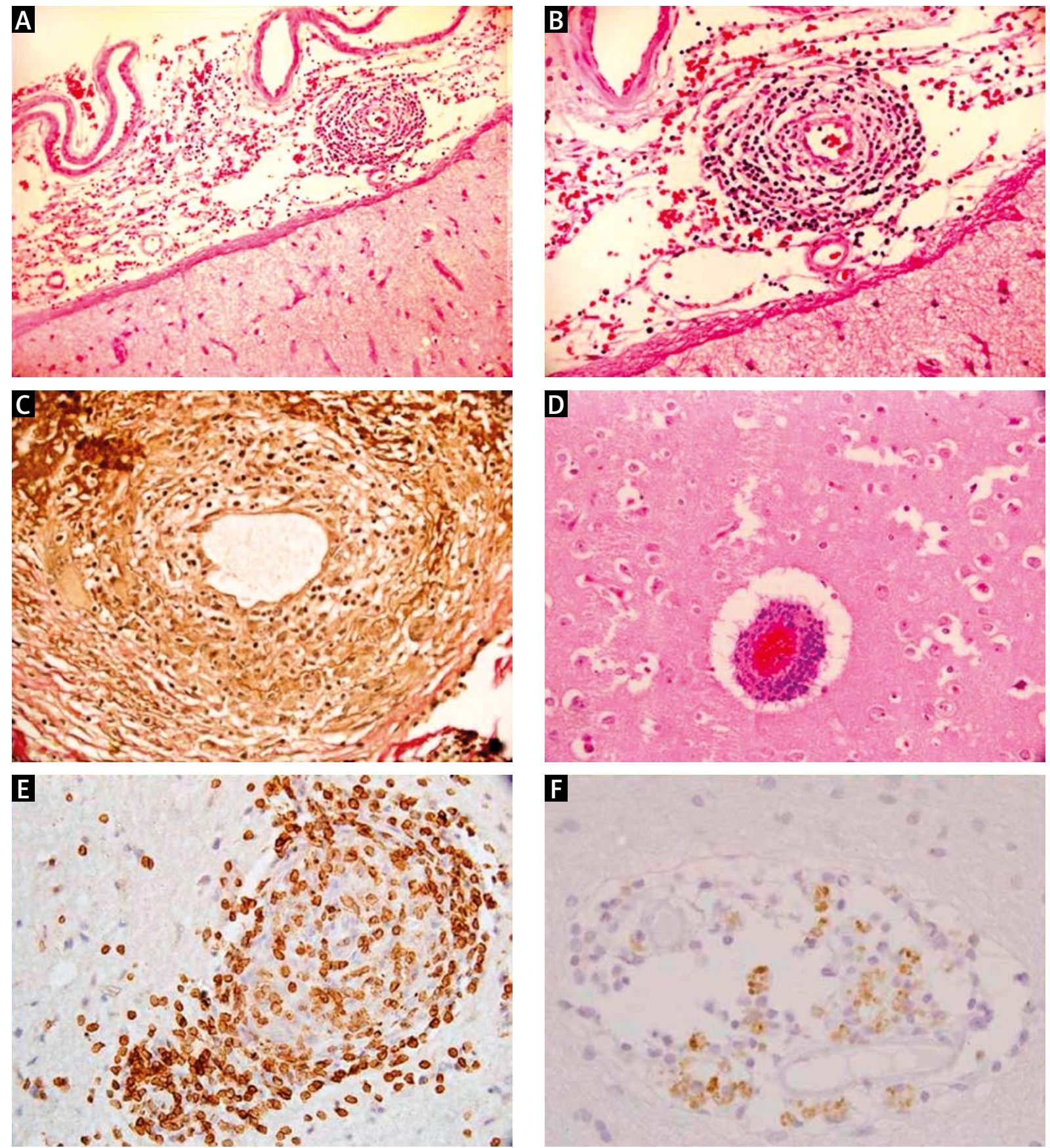

Fig. 4. Photomicrographs of case 4 showing (A) lymphocytic infiltrates within the wall of a leptomeningeal artery; there is no significant inflammatory infiltrate in the adjacent cortex (H\&E, $\times 100)$. High power view (B) showing complete destruction of the vessel wall (H\&E, $\times 200)$. VVG stain (C) demonstrates loss of internal elastic lamina (VVG, $\times 400)$. Cortical blood vessels (D) showed similar features (H\&E, $\times 200)$. The inflammatory cells are predominantly CD3+ T cells (E) with only few CD20+ B cells (F) (IHC, $\times 400)$. 
angiogram with abnormal findings on MRI and a CSF profile consistent with PACNS [5].

\section{Clinical profile}

The clinical manifestations of PACNS are diverse and non-specific. Giannini et al. summarized clinical findings in a 25-year follow up of 131 consecutive patients seen at the Mayo Clinic over a period of 25 years [12]. Headache, altered cognition, and persistent neurologic deficit or stroke were the most common manifestations, observed in $62 \%$, 53\% and $39 \%$ of cases, respectively. As part of a recent study of 101 consecutive patients with PCNSV seen at the Mayo Clinic over a 21-year period, and further from the updated cohort of 131 patients, Salvarani et al. identified several subsets of PCNSV which have distinct clinical, radiological and histopathological patterns, and also differ in terms of prognosis and optimal management $[30,35,36]$. Four subsets were identified from the cohort of 101 patients, which included a) PACNS with cerebral amyloid angiopathy (CAA); b) PACNS with spinal cord involvement; c) PACNS with prominent leptomeningeal enhancement; and d) angiography negative PACNS. Eight (26\%) out of 31 cases with CNS biopsy specimens positive for PCNSV also showed findings of vascular amyloid deposits (CAA). All had a granulomatous vascular inflammatory pattern. Compared with patients with PCNSV only, these patients were older at diagnosis, predominantly male, had a more acute onset, a higher frequency of cognitive dysfunction and showed prominent gadolinium-enhanced leptomeningeal lesions on MRI [37]. Five cases had documented evidence of spinal cord involvement. Most patients had concurrent or subsequent brain involvement during the disease course. The thoracic cord was predominantly affected. The authors suggested that careful medical evaluation must be performed to exclude other conditions associated with acute or subacute transverse myelitis [36]. None of the cases in the present series showed either spinal cord involvement or histopathological evidence of amyloid deposition.

$M R I$ showed prominent leptomeningeal enhancement in 8 of 101 patients with PCNSV. In six of those, cerebral angiography or magnetic resonance angiography results were normal, but biopsy from the brain or spinal cord showed vasculitis in all eight. Granulomatous vascular inflammation was found in six spec- imens. All eight patients showed a prompt response to therapy. The authors suggested that prominent gadolinium leptomeningeal enhancement on MRI may point to a distinct subtype of PCNSV with small leptomeningeal artery vasculitis and rapid response to therapy [31].

In 2005, Benseler and co-workers described a new disease entity, viz. angiography-negative primary CNS vasculitis of childhood. The authors studied four children with primary CNS vasculitis in whom results of magnetic resonance imaging studies were abnormal but results of conventional angiography were normal [4]. Further, on retrospective analysis of the series of 101 patients, Salvarani et al. also identified eight patients with angiography negative PCNSV.

On using the updated cohort of 131 consecutive patients at the Mayo Clinic, 11 cases with rapidly progressive PCNSV were documented [12]. This subset represents the worst end of the clinical spectrum of this vasculitis, characterized by bilateral, multiple, large cerebral vessel lesions, multiple CNS infarctions and poor response to traditional immunosuppressive therapy. In this cohort of 131 patients, sixteen patients (12.2\%) had evidence of intracranial haemorrhage at or near the time of diagnosis. A necrotizing histopathologic pattern of vasculitis was observed in 3 of the 4 patients with positive biopsy findings (75\%) [12].

In 2008, Molloy et al. examined the case records of the Cleveland Clinic (CC), Massachusetts General Hospital $(\mathrm{MGH})$, and the English language medical literature, for biopsy-proven PACNS cases presenting as a solitary mass lesion (ML). They identified a total of $38 \mathrm{ML}$ : eight of 202 (4.0\%) patients from CC/MGH and 30 of 535 (5.6\%) patients identified from the medical literature. Excision of the lesion may be curative; however, in some patients aggressive immunosuppressive therapy has led to a favourable outcome obviating the need of surgery [23].

\section{Primary angiitis of central nervous system in children}

Primary angiitis of central nervous system in the paediatric age group is poorly characterized. There are only few case reports and case series. Although the disease was earlier thought to be rare, recent studies have shown that childhood PACNS could be an important cause of vascular stroke in children [3]. Diagnostic features are based on rare autopsy find- 
ings and, more recently, on angiographic findings $[4,14,32]$. Distinct phenotypes in children include progressive, angiography-positive, medium-to-large vessel CNS vasculitis; non-progressive, angiography-positive, medium to-large vessel CNS vasculitis; angiography-negative, small-vessel CNS vasculitis, confirmed by brain biopsy [4,32].

\section{Neuroimaging}

Magnetic resonance imaging is abnormal in almost all cases, with a sensitivity of $90-100 \%$, and is the main neuroradiological modality for workup of these patients $[5,26]$. Abnormalities may be seen in the subcortical white matter, deep gray matter, the deep white matter, and the cerebral cortex [28]. Infarcts may be seen in approximately $50 \%$ of cases [32]. Other common patterns include diffuse small vessel changes of ischaemic demyelination. Both subarachnoid and intraparenchymal haemorrhages have been observed in $10 \%$ of cases. Leptomeningeal enhancement may be seen in $10 \%$ of cases [31]. Mass lesions may be seen in $5 \%$ of cases, and generally mimic a tumour or abscess [23]. Rarely, confluent white-matter lesions may be seen $[5,33,41]$.

Angiographic features considered diagnostic of PACNS include multiple "beading" or segmental narrowing, in large, intermediate, or small arteries with interposed regions of ectasia or normal luminal architecture $[9,13,17]$. Angiography however has limited sensitivity (20-90\%) and specificity (20$60 \%$ ). Angiographic changes typical of vasculitis may be seen in non-vasculitic conditions such as vasospasm, atherosclerosis, CNS infections, lymphomas, cerebral arterial emboli, and radiation vasculopathy $[2,11,19,25]$. Angiography may be normal in vasculitis limited to small vessels below the resolution of conventional angiography [30]. Hence, angiography results should always be interpreted in conjunction with clinical, laboratory, and MRI findings.

\section{Histopathological spectrum}

Brain biopsy remains the gold standard for the diagnosis of PACNS. Histopathological evaluation is crucial not only for making the diagnosis of PACNS but also to rule out mimics, especially infections and malignancy. In a recent study by Giannini et al., biopsies were non diagnostic in $35 \%$ of cases [12]. This is attributed to the inherent patchiness of vasculitic inflammation, or to the fact that the affected vessels may be of a large diameter and hence do not extend to the superficial parenchyma and leptomeninges $[12,14]$. To enhance the diagnostic yield, targeted biopsies should be performed with inclusion of leptomeninges $[6,22]$.

The most common histological pattern is of granulomatous vasculitis, characterized by vasculocentric mononuclear inflammation associated with wellformed granulomas and multinucleated giant cells and at least focal vessel wall destruction. Giannini et al. observed this pattern in $58 \%$ of cases [12]. Lymphocytic vasculitis is the second most predominant pattern. There is marked perivascular lymphocytic inflammation with occasional plasma cells, extending through the vascular wall with vascular distortion and destruction. There is absence of significant parenchymal inflammation [12,14]. The least frequent pattern is that of acute necrotizing vasculitis, characterized by acute inflammation and transmural fibrinoid necrosis. It involves predominantly small muscular arteries [12]. The histological patterns, as observed in patients who have undergone repeat biopsies, remain stable over time, suggesting that they are truly distinct patterns rather than different stages of disease [35]. In the recently updated series of 131 patients from the Mayo Clinic, the granulomatous pattern was seen in $56 \%$, pure lymphocytic in $20 \%$ and acute necrotizing pattern in $22 \%$ of cases [12]. Concurrent parenchymal ischaemia/infarct was found in $51 \%$ of cases. Eleven cases (27\%) with CNS biopsy specimens positive for PCNSV also showed findings of CAA. All the cases with CAA showed granulomatous inflammation [12]. In the present series, $62.5 \%$ showed granulomatous vasculitis, $25 \%$ lymphocytic vasculitis and $12.5 \%$ acute necrotizing vasculitis.

\section{Treatment}

There are no randomized clinical trials on drug therapy in PCNSV. Treatment recommendations have been extrapolated from therapeutic strategies used in other vasculitides. In general, a combination of steroids and pulsed cyclophosphamide is recommended. TNF-alpha blockers and mycophenolate mofetil have successfully been used to treat patients with PCNSV resistant to glucocorticoids and immunosuppressants $[34,39]$.

To conclude, in view of non-specific clinical presentations and lack of highly efficient non-invasive 
modalities, diagnosis of PACNS is a challenge and requires a high index of clinical suspicion, with appropriate work-up to exclude other conditions. Increased recognition and better understanding of the molecular pathogenesis of this entity will provide a key to prognostication and therapeutic decision making.

\section{Disclosure}

\section{Authors report no conflict of interest.}

\section{References}

1. Alba MA, Espígol-Frigolé G, Prieto-González S, Tavera-Bahillo I, García-Martínez A, Butjosa M, Hernández-Rodríguez J, Cid MC. Central nervous system vasculitis: still more questions than answers. Curr Neuropharmacol 2011; 9: 437-448.

2. Alhalabi M, Moore PM. Serial angiography in isolated angiitis of the central nervous system. Neurology 1994; 44: 1221-1226.

3. Amlie-Lefond C, Bernard TJ, Sebire G, Friedman NR, Heyer GL, Lerner NB, deVeber G, Fullerton HJ. Predictors of cerebral arteriopathy in children with ischemic stroke: results of the International Pediatric Stroke study. Circulation 2009; 119: 1417-1423.

4. Benseler SM, deVeber G, Hawkins C, Schneider R, Tyrrell PN, Aviv RI, Armstrong D, Laxer RM, Silverman ED. Angiographynegative primary central nervous system vasculitis in children: a newly recognized inflammatory central nervous system disease. Arthritis Rheum 2005; 52: 2159-2167.

5. Birnbaum J, Hellmann DB. Primary angiitis of the central nervous system. Arch Neurol 2009; 66: 704-709.

6. Calabrese LH, Furlan AJ, Gragg LA, Ropos TJ. Primary angiitis of the central nervous system: diagnostic criteria and clinical approach. Cleve Clin J Med 1992; 59: 293-306.

7. Calabrese LH, Mallek JA. Primary angiitis of the central nervous system. Report of 8 new cases, review of the literature, and proposal for diagnostic criteria. Medicine 1988; 67: 20-39.

8. Carolei A, Sacco S. Central nervous system vasculitis. Neurol Sci 2003; 24: S8-S10.

9. Cloft HJ, Phillips CD, Dix JE, McNulty BC, Zagardo MT, Kallmes DF. Correlation of angiography and MR imaging in cerebral vasculitis. Acta Radiol 1999; 40: 83-87.

10. Cravioto H, Feigin I. Noninfectious granulomatous angiitis with a predilection for the nervous system. Neurology 1959; 9: 599-609.

11. Duna GF, Calabrese LH. Limitations of invasive modalities in the diagnosis of primary angiitis of the central nervous system. J Rheumatol 1995; 22: 662-667.

12. Giannini C, Salvarani C, Hunder G, Brown RD. Primary central nervous system vasculitis: pathology and mechanisms. Acta Neuropathol 2012; 123: 759-772.

13. Greenan TJ, Grossman RI, Goldberg HI. Cerebral vasculitis, MR imaging and angiographic correlation. Radiology 1992; 182: 65-72.

14. Hajj-Ali RA, Singhal AB, Benseler S, Molloy E, Calabrese LH. Primary angiitis of the CNS. Lancet Neurol 2011; 10: 561-572.
15. Harbitz F. Unknown forms of arteritis with special reference to their relation to syphilitic arteritis and periarteritis nodosa. Am J Med Sci 1922; 163: 250-272.

16. Harris KG, Tran DD, Sickels WJ, Cornell SH, Yuh WT. Diagnosing intracranial vasculitis: the roles of MR and angiography. Am J Neuroradiol 1994; 15: 317-330.

17. Hellmann DB, Roubenoff R, Healy RA, Wang H. Central nervous system angiography, Safety and predictors of a positive result in 125 consecutive patients evaluated for possible vasculitis. J Rheumatol 1992; 19: 568-572.

18. Iwase T, Ojika K, Mitake S, Katada E, Katano H, Mase M, Yoshida S, Ueda R. Involvement of CD45RO+ T lymphocyte infiltration in a patient with primary angiitis of the central nervous system restricted to small vessels. Eur Neurol 2001; 45: 184-185.

19. Kadkhodayan Y, Alreshaid A, Moran CJ, Cross DT 3rd, Powers WJ, Derdeyn CP. Primary angiitis of the central nervous system at conventional angiography. Radiology 2004; 233: 878-882.

20. Kelley RE. CNS vasculitis. Front Biosci 2004; 9: 946-955.

21. MacLaren K, Gillespie J, Shrestha S, Neary D, Ballardie FW. Primary angiitis of the central nervous system: emerging variants. Q J Med 2005; 98: 643-654.

22. Miller DV, Salvarani C, Hunder GG, Brown RD, Parisi JE, Christianson TJ, Giannini C. Biopsy findings in primary angiitis of the central nervous system. Am J Surg Pathol 2009; 33: 35-43.

23. Molloy ES, Singhal AB, Calabrese LH. Tumour-like mass lesion: an under-recognized presentation of primary angiitis of the central nervous system. Ann Rheum Dis 2008; 67: 1732-1735.

24. Moore PM, Richardson B. Neurology of the vasculitides and connective tissue diseases. J Neurol Neurosurg Psychiatry 1998; 65: 10-22.

25. Moore PM. Diagnosis and management of isolated angiitis of the central nervous system. Neurology 1989; 39: 167-173.

26. Néel A, Pagnoux C. Primary angiitis of the central nervous system. Clin Exp Rheumatol 2009; 27: S95-S107.

27. Pagni F, Isimbaldi G, Vergani F, Casiraghi P, Marzorati L, Migliorino G, Cattoretti G. Primary angiitis of the central nervous system: 2 atypical cases. Folia Neuropathol 2012; 50: 293-299.

28. Pomper MG, Miller TJ, Stone JH, Tidmore WC, Hellmann DB. CNS vasculitis in autoimmune disease: MR imaging findings and correlation with angiography. Am J Neuroradiol 1999; 20 : 75-85.

29. Rollnik JD, Brandis A, Dehghani K, Bufler J, Lorenz M, Heidenreich F, Donnerstag F. Primary angiitis of CNS (PACNS). Nervenarzt 2001; 72: 798-801.

30. Salvarani C, Brown RD Jr, Calamia KT, Christianson TJ, Huston J 3rd, Meschia JF, Giannini C, Miller DV, Hunder GG. Angiography-negative primary central nervous system vasculitis: a syndrome involving small cerebral vessels. Medicine 2008; 87 : 264-271.

31. Salvarani C, Brown RD Jr, Calamia KT, Christianson TJ, Huston J 3rd, Meschia JF, Giannini C, Miller DV, Hunder GG. Primary central nervous system vasculitis with prominent leptomeningeal enhancement: a subset with a benign outcome. Arthritis Rheum 2008; 58: 595-603.

32. Salvarani C, Brown RD Jr, Calamia KT, Christianson TJ, Huston J 3rd, Meschia JF, Giannini C, Miller DV, Hunder GG. Primary cen- 
tral nervous system vasculitis presenting with intracranial hemorrhage. Arthritis Rheum 2011; 63: 3598-3606.

33. SalvaraniC, Brown RD Jr, Calamia KT, Christianson TJ, Weigand SD, Miller DV, Giannini C, Meschia JF, Huston J 3rd, Hunder GG. Primary central nervous system vasculitis, analysis of 101 patients. Ann Neurol 2007; 62: 442-451.

34. Salvarani C, Brown RD Jr, Calamia KT, Huston J 3rd, Meschia JF, Giannini C, Miller DV, Hunder GG. Efficacy of tumor necrosis factor alpha blockade in primary central nervous system vasculitis resistant to immunosuppressive treatment. Arthritis Rheum 2008; 59: 291-296.

35. Salvarani C, Brown RD Jr, Hunder GG. Adult primary central nervous system vasculitis: an update. Curr Opin Rheumatol 2012; 24: 46-52.

36. Salvarani C, Brown RD Jr., Calamia KT, Christianson TJ, Huston 3rd, Meschia JF, Giannini C, Miller DV, Hunder GG. Primary CNS vasculitis with spinal cord involvement. Neurology 2008; 70 2394-2400.

37. Salvarani C, Brown RD Jr., Calamia KT, Christianson TJ, Huston J 3rd, Meschia JF, Giannini C, Miller DV, Hunder GG. Primary central nervous system vasculitis: comparison of patients with and without cerebral amyloid angiopathy. Rheumatology 2008; 47: 1671-1677.

38. Scolding NJ. Central nervous system vasculitis. Semin Immunopathol 2009; 31: 527-536.

39. Sen ES, Leone V, Abinun M, Forsyth R, Ramesh V, Friswell M, O'Callaghan F, Ramanan AV. Treatment of primary angiitis of the central nervous system in childhood with mycophenolate mofetil. Rheumatology 2010; 49: 806-811.

40. Siva A. Vasculitis of the nervous system. J Neurol 2001; 248: 451-468.

41. Zuccoli G, Pipitone N, Haldipur A, Brown RD Jr, Hunder G, Salvarani $C$. Imaging findings in primary central nervous system vasculitis. Clin Exp Rheumatol 2011; 29: S104-S109. 